\title{
Selective digestive decontamination solution used as "lock therapy" prevents and eradicates bacterial biofilm in an in vitro bench-top model
}

\author{
María Jesús Pérez-Granda 1,2,3, Beatriz Alonso ${ }^{2,4,8^{*}}$, Ricardo Zavala ${ }^{5}$, María Consuelo Latorre ${ }^{5}$, Javier Hortal ${ }^{1,3}$,
} Rafael Samaniego ${ }^{2,6}$, Emilio Bouza $^{7}$, Patricia Muñoz ${ }^{2,3,4,7}$ and María Guembe ${ }^{2,4,8^{*}}$ (1)

\begin{abstract}
Background: Most preventing measures for reducing ventilator-associated pneumonia (VAP) are based mainly on the decolonization of the internal surface of the endotracheal tubes (ETTs). However, it has been demonstrated that bacterial biofilm can also be formed on the external surface of ETTs. Our objective was to test in vitro the efficacy of selective digestive decontamination solution (SDDs) onto ETT to prevent biofilm formation and eradicate preformed biofilms of three different microorganisms of VAP.
\end{abstract}

Methods: We used an in vitro model in which we applied, at the subglottic space of ETT, biofilms of either P. aeruginosa ATCC 15442, or E. coli ATCC 25922, or S. aureus ATCC 29213, and the SDDs at the same time (prophylaxis) or after $72 \mathrm{~h}$ of biofilm forming (treatment). ETT were incubated during 5 days with a regimen of $2 \mathrm{~h}$-locks. ETT fragments were analyzed by sonication and confocal laser scanning microscopy to calculate the percentage reduction of cfu and viable cells, respectively.

Results: Median (IQR) percentage reduction of live cells and cfu/ml counts after treatment were, respectively, 53.2\% (39.4\%-64.1\%) and 100\% (100\%-100.0\%) for P. aeruginosa, and 67.9\% (46.7\%-78.7\%) and 100\% (100\%-100.0\%) for E. coli. S. aureus presented a complete eradication by both methods. After prophylaxis, there were absence of live cells and $\mathrm{cfu} / \mathrm{ml}$ counts for all microorganisms.

Conclusions: SDDs used as "lock therapy" in the subglottic space is a promising prophylactic approach that could be used in combination with the oro-digestive decontamination procedure in the prevention of VAP.

Keywords: Ventilator associated pneumonia, Biofilm, Endotracheal tube, Selective decontamination solution, Lock therapy

\footnotetext{
*Correspondence: beaafm@hotmail.com; mariaguembe@hotmail.com ${ }^{8}$ Servicio de Microbiología Clínica y Enfermedades Infecciosas, Instituto de Investigación Sanitaria Gregorio Marañón, Hospital General Universitario "Gregorio Marañón", C/. Dr. Esquerdo, 46, Madrid 28007, Spain

Full list of author information is available at the end of the article
}

\begin{abstract}
Background
Ventilator-associated pneumonia (VAP) is one of the most common pulmonary nosocomial infections in intensive care units (ICU), not only in developed but also in developing countries, with an incidence of $9 \%$ to $27 \%$ in intubated patients increasing to $46 \%$ in patients who need mechanical ventilation for more than $48 \mathrm{~h}$ after major heart surgery [1-5]. VAP represents high rates of
\end{abstract}

(c) The Author(s) 2020. This article is licensed under a Creative Commons Attribution 4.0 International License, which permits use, sharing, adaptation, distribution and reproduction in any medium or format, as long as you give appropriate credit to the original author(s) and the source, provide a link to the Creative Commons licence, and indicate if changes were made. The images or other third party material in this article are included in the article's Creative Commons licence, unless indicated otherwise in a credit line to the material. If material is not included in the article's Creative Commons licence and your intended use is not permitted by statutory regulation or exceeds the permitted use, you will need to obtain permission directly from the copyright holder. To view a copy of this licence, visit http://creativeco mmons.org/licenses/by/4.0/. The Creative Commons Public Domain Dedication waiver (http://creativecommons.org/publicdomain/ zero/1.0/) applies to the data made available in this article, unless otherwise stated in a credit line to the data. 
morbidity and mortality, longer hospital stays, and additional sanitary costs [6].

Although pulmonary aspiration of oropharyngeal and gastric microorganisms are the endogenous rout of airway colonization, the ability of bacteria to form biofilm on endotracheal tube (ETT) surface is thought to be one of the most important external risk factors of VAP development [6-10]. There are several strategies to prevent and treat VAP focused mainly in the internal surface of the ETT, including: selective digestive and oral decontamination (SDD/SOD), use of oral antiseptics, subglottic aspiration, elevation of the head of bed, ETT surface modifications such as antimicrobial-drug coated tubes or silver-coated ETT, mucus removal, and parenteral antimicrobial therapy $[9,11-19]$.

SDD refers to a prophylactic strategy based on the application of non-absorbable antimicrobial agents in the oropharynx and gastrointestinal tract [20-22]. SDD solution (SDDs) is mainly composed of tobramycin, polymyxins and amphotericin B with antimicrobial activity against gram negative microorganisms, including multidrug resistant, gram positive, and yeasts; which are the most common causative microorganisms in VAP [1, 20, 22-25]. SDDs was designed to attack only aerobic bacteria potentially pathogenic in the oral cavity and in the digestive tract leaving anaerobic normal microbiota undisturbed [26]. Although there are several studies regarding the efficacy and safety of SDDs in ICU patients $[20,27,28]$ literature about its efficacy as antibiotic lock therapy (ALT) or antibiotic lock prophylaxis (ALP) is scarce to the best of our knowledge [29].

Thus, our objective was to assess the efficacy of SDDs as prophylaxis and treatment of bacterial biofilm administered in the external surface of the subglottic space using an in vitro bench model [30].

\section{Methods}

This study was carried out in the laboratory of the Clinical Microbiology and Infectious Diseases Department, Hospital Gregorio Marañón, Madrid, Spain.

Confocal laser scanning microscopy (CLSM) images were performed in the CLSM unit of the Instituto de Investigación Sanitaria Gregorio Marañón. Scanning electron microscopy (SEM) images were performed in the Centro Nacional de Microscopía de Barrido de la Universidad Complutense de Madrid.

\section{Therapies}

An adult tracheal intubation was simulated using cuffed ETT (TaperGuard Oral Tracheal Tube Evac Murphy Eye, Mallinckrodt $^{\mathrm{TM}}$ ) as shown in Fig. 1 [31].

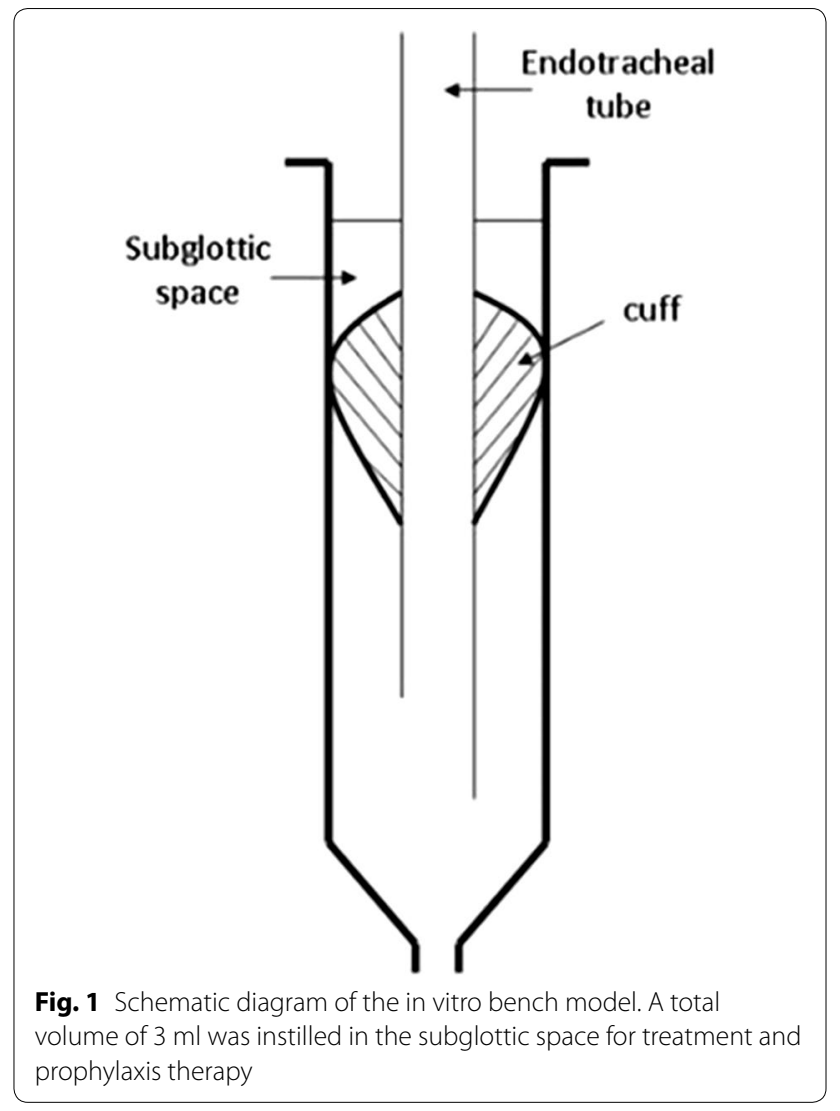

\section{Treatment therapy}

Mature-biofilms: The ETTs were colonized with $3 \mathrm{ml}$ of 0.5 McFarland culture of Pseudomonas aeruginosa ATCC 15442, or Escherichia coli ATCC 25922, or Staphylococcus aureus ATCC 29213 in their culture medium (BHI, LB, and TSB respectively) (Sigma-aldrich, Spain). ETT were culture at $37^{\circ} \mathrm{C}$ for $72 \mathrm{~h}$ with 24 -h medium replacement performed daily at the same time (Additional file 1: Fig. S1).

Lock therapy: ALT was based on a 2-hour application at the mature biofilms of $3 \mathrm{ml}$ in the subglottic area of either SDDs (nystatin $2.6 \mathrm{mIU}$, tobramycin $15.6 \mathrm{mg} / \mathrm{ml}$, and colimycin $13 \mathrm{mg} / \mathrm{ml}$. In the case of $S$. aureus, vancomycin $3.6 \mathrm{mg} / \mathrm{ml}$ was also added) after a washing with sterile saline in the treated samples or sterile saline $(0.9 \%$ $\mathrm{NaCl}$ ) in positive controls. Then, solutions were removed and ETT were washed with sterile saline and incubated with fresh medium at $37^{\circ} \mathrm{C}$ for $22 \mathrm{~h}$. Antibiotic lock solution was repeated during 5 days. Medium without microorganism was used as negative control. All samples were tested six times. 


\section{Prophylactic therapy}

The ETTs were colonized simultaneously with $1.5 \mathrm{ml}$ of a 0.5 McFarland culture of $P$. aeruginosa ATCC 15442, or E.coli ATCC 25922, or S. aureus ATCC 29213 in their culture medium (BHI, LB, and TSB respectively) and $1.5 \mathrm{ml}$ of either SDDs in the treated samples or sterile saline $(0.9 \% \mathrm{NaCl})$ in positive controls. In this ALP, final concentrations of nystatin, tobramycin, colimycin, and vancomycin were as follow: $1.3 \mathrm{mIU}, 7.8 \mathrm{mg} / \mathrm{ml}, 6.5 \mathrm{mg} /$ $\mathrm{ml}$, and $1.8 \mathrm{mg} / \mathrm{ml}$, respectively.

ETTs were incubated at $37{ }^{\circ} \mathrm{C}$ for $2 \mathrm{~h}$. Solutions were discarded and ETT were washed with sterile saline and incubated in fresh medium for $22 \mathrm{~h}$ at $37{ }^{\circ} \mathrm{C}$. The procedure was repeated during 5 days. Medium without microorganism was used as negative control. All samples were tested six times.

After each therapy, ETT were washed with sterile saline before analysis.

\section{ETTs analysis}

ETTs were cut into 3 segments of $0.5 \mathrm{~cm}$ (Fig. 2). Each segment was used for a different analysis.
Colony forming unit counts and percentage of live cells. One segment was sonicated in $2 \mathrm{ml}$ of buffer solution for $1 \mathrm{~min}$ at $50 \mathrm{~Hz}$ and vigorously vortexed. Solution was then serially diluted and $100 \mu \mathrm{l}$ were cultured on blood agar plates and incubated for $24 \mathrm{~h}$ at $37^{\circ} \mathrm{C}$. We scrubbed ETT surface of positive controls with a sterile swab and was introduced in $1 \mathrm{ml}$ of PBS and $100 \mu \mathrm{l}$ of the solution were plated on agar plates and incubated for $24 \mathrm{~h}$ at $37^{\circ} \mathrm{C}$.

Colony counts were expressed as the number of $\mathrm{cfu} / \mathrm{ml}$ with a limit of detection of $<10 \mathrm{cfu} / \mathrm{ml}$. Live/dead analysis was performed by centrifuging the remaining sonicate to study the viability of bacteria. Pellet was resuspended in $50 \mu \mathrm{l}$ of sterile saline and stained with Live/Dead ${ }^{\circledR}$ BacLight kit ${ }^{\mathrm{TM}}\left(0.5 \mu \mathrm{l}\right.$ of SYTO ${ }^{\circledR}$ 9, stock $3.34 \mathrm{mM}$ in DMSO; and $0.5 \mu \mathrm{l}$ propidium iodide, stock $20 \mathrm{mM}$ in DMSO) (BacLight kit ${ }^{\mathrm{TM}}$; Invitrogen, Barcelona, Spain) for $15 \mathrm{~min}$ protected from light. A drop (5 $\mu$ l) of each dilution was mounted on a coverslip and visualized using a confocal laser scanning microscopy (CLSM) in an inverted confocal fluorescence microscope (SPE, Leica Microsystems) equipped with ACS APO 10x/0.30 and ACS APO

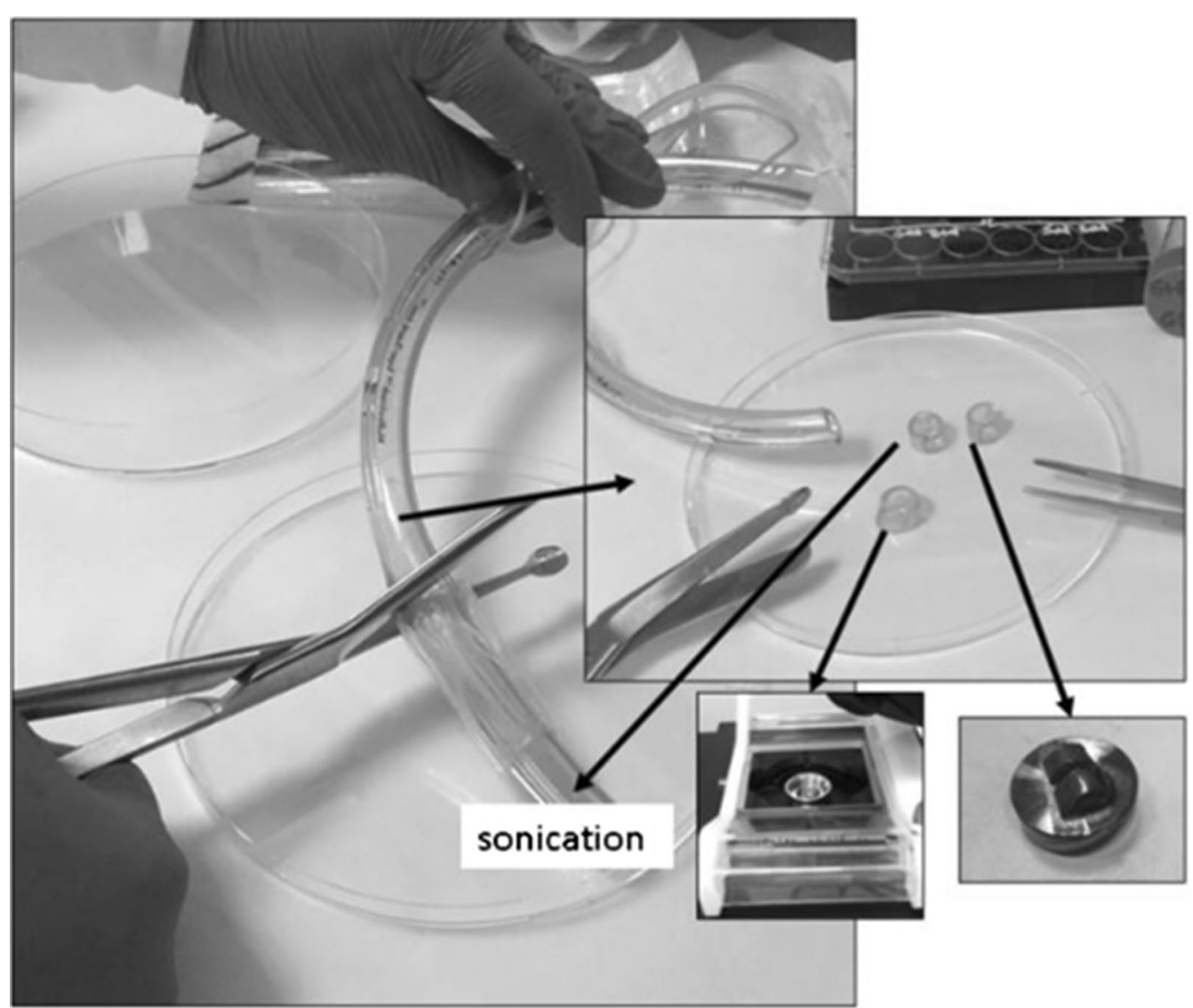

Fig. 2 ETT analysis 
$63 \mathrm{X} / 1.30$ objectives. Images were taken using an ACS APO $63 \mathrm{X} / 1.30$ objective. Three images containing over 1000 cells per condition were taken from each sample. Quantification of live and dead cells was performed by using FIJI software (National Institute of Health, US). The percentage of live bacteria was calculated as the ratio between the number of live cells and the total number of cells $\times 100$.

Visualization of biofilm biomass. Another segment was fixed by freezing at $-80{ }^{\circ} \mathrm{C}$ for $72 \mathrm{~h}$. After thawing for $30 \mathrm{~min}$ at room temperature, segments were stained with Live/Dead ${ }^{\circledR}$ BacLight kit $^{\mathrm{TM}}\left(1.5 \mu \mathrm{l}\right.$ of SYTO ${ }^{\circledR}$ 9, stock $3.34 \mathrm{mM}$ in DMSO; and $1.5 \mu \mathrm{l}$ propidium iodide, stock $20 \mathrm{mM}$ in DMSO in $1 \mathrm{ml}$ of buffer solution) for $15 \mathrm{~min}$ protected from light [32]. Samples were visualized using CLSM at ACS APO 10X/0.3 objective. Images were edited using FIJI software (National Institute of Health, US).

Visualization of biofilm structure. The last segment was used to visualize biofilm structure by scanning electron microscopy (SEM). Segments were placed into $2 \%$ glutaraldehyde for 3 days and after dehydration in graded alcohol, samples were sputter-coated with gold atoms. The structure of the treated and non-treated biofilms was visualized using a scanning electron microscope (JEOLJSM 6400; Jeol, Tokyo, Japan).

\section{Filtration testing}

In order to assess whether "lock therapy" in ETT could leak past the cuff, our bench model was hold into a Falcon tube to recover any filtration of the SDD solution during the therapies.

\section{Statistical analysis}

Qualitative variables appear with their frequency distribution. Quantitative variables are expressed as the median and interquartile range (IQR). Non-normally distributed continuous variables were compared using the Kruskal-Wallis and Mann-Whitney tests.

All statistical tests were 2-tailed. Statistical significance was set at $\mathrm{p}<0.05$ for all the tests. The statistical analysis was performed with IBM SPSS Statistics 21.0 for Windows (IBM, New York).

\section{Results}

\section{Overall data}

Overall data of the median (IQR) percentage and median (IQR) percentage reduction of live cells and $\log _{10} \mathrm{cfu} / \mathrm{ml}$ for ALT and ALP therapies for P. aeruginosa, E. coli, and S. aureus are shown in Table 1.

Reduction in live cells and cfu counts was statistically significant in both therapies for all microorganisms. Moreover, this reduction reached $100 \%$ for all microorganisms in both therapies except for live cells of $P$. aeruginosa and E. coli.

\section{Treatment therapy (ALT)}

Median (IQR) percentage reduction of live cells of $P$. aeruginosa, E. coli, and S. aureus treated samples were, respectively (Table 1): $53.2 \%$ (39.4\%-64.1\%), 67.9\% (46.7\%-78.7\%), and $100 \%(100 \%-100 \%)$, which corresponded to a statistical significant reduction on the percentage of live cells between treated and non-treated samples $(\mathrm{p}<0.001, \mathrm{p}=0.002$, and $\mathrm{p}=0.007$, respectively) (Fig. 3). Percentage reduction of $\mathrm{cfu} / \mathrm{ml}$ was $100 \%$ for P. aeruginosa, E. coli, and S. aureus treated

Table 1 Overall data of live cells, cfu/ml counts, and percentage of reduction of bacterial biofilms after prophylaxis and treatment with selective digestive decontamination solution

\begin{tabular}{|c|c|c|c|c|c|c|c|c|c|}
\hline \multirow[t]{2}{*}{ Therapy } & \multirow[t]{2}{*}{ MO } & \multicolumn{2}{|c|}{ Median (IQR) \% live cells } & \multirow{2}{*}{$\begin{array}{l}\text { Median (IQR) \% } \\
\text { reduction of live } \\
\text { cells }\end{array}$} & \multirow[t]{2}{*}{$P$ value } & \multicolumn{2}{|c|}{$\begin{array}{l}\text { Median (IQR) } \log _{10} \\
\mathrm{cfu} / \mathrm{ml}^{*}\end{array}$} & \multirow{2}{*}{$\begin{array}{l}\text { Median (IQR) } \% \\
\text { reduction** of cfu/ } \\
\mathrm{ml}^{*}\end{array}$} & \multirow[t]{2}{*}{$P$ value } \\
\hline & & $\mathrm{C}+$ & ALT & & & $\mathrm{C}+$ & ALT & & \\
\hline \multirow[t]{3}{*}{ Treatment } & P. aeruginosa & $88.9(84.4-93.4)$ & $39.3(30.1-50.9)$ & $53.2(39.4-64.1)$ & $<0.001$ & $7.5\left(7.4-{ }^{b}\right)$ & $-{ }^{\mathrm{a}}$ & $100.0(100.0-100.0)$ & 0.002 \\
\hline & E. coli & $55.9(49.6-67.3)$ & $18.8(12.5-31.2)$ & $67.9(46.7-78.7)$ & 0.002 & $7.0(6.7-7.4)$ & $-{ }^{a}$ & $100.0(100.0-100.0)$ & 0.002 \\
\hline & S. aureus & $42.9(28.7-57.5)$ & $0.0(0.0-0.0)$ & $100.0(100.0-100.0)$ & 0.007 & $7.7(7.5-7.9)$ & $-{ }^{a}$ & $100.0(100.0-100.0)$ & 0.002 \\
\hline \multirow[t]{3}{*}{ Prophylaxis } & P. aeruginosa & $83.1(77-88.4)$ & $0.0(0.0-0.0)$ & $100.0(100.0-100.0)$ & $<0.001$ & $7.4(6.9-8.4)$ & $-^{a}$ & ${ }^{* *}$ Absence & 0.004 \\
\hline & E. coli & $43.9(34.1-46.1)$ & $0.0(0.0-0.0)$ & $100.0(100.0-100.0)$ & $<0.001$ & $7.2(6.9-7.34)$ & $-{ }^{\mathrm{a}}$ & ${ }^{*}$ Absence & 0.002 \\
\hline & S. aureus & $32.7(23.7-49.7)$ & $0.0(0.0-0.0)$ & $100.0(100.0-100.0)$ & 0.008 & $7.6(7.4-7.8)$ & $-{ }^{a}$ & ${ }^{* *}$ Absence & 0.002 \\
\hline
\end{tabular}

$P$ values were obtained using Mann-Whitney $U$ test

$M O$ microorganism, IQR interquartile range, cfu colony forming units, $C+$ positive control, $A L T$ antibiotic lock therapy

a No cells were recovered after therapy. $\mathrm{Cfu} / \mathrm{ml}$ resulted to be $0(0.0-0.0)$ for all microorganisms after every therapy being log ${ }_{10}$ of 0 in-calculated

b No p75 value obtained

* Limit of detection of cfu counting using conventional culture was $10 \mathrm{cfu} / \mathrm{ml}$

**In prophylaxis therapy, no reduction could be measured, as there was no pre-formed biofilm. Results are expressed as absence 


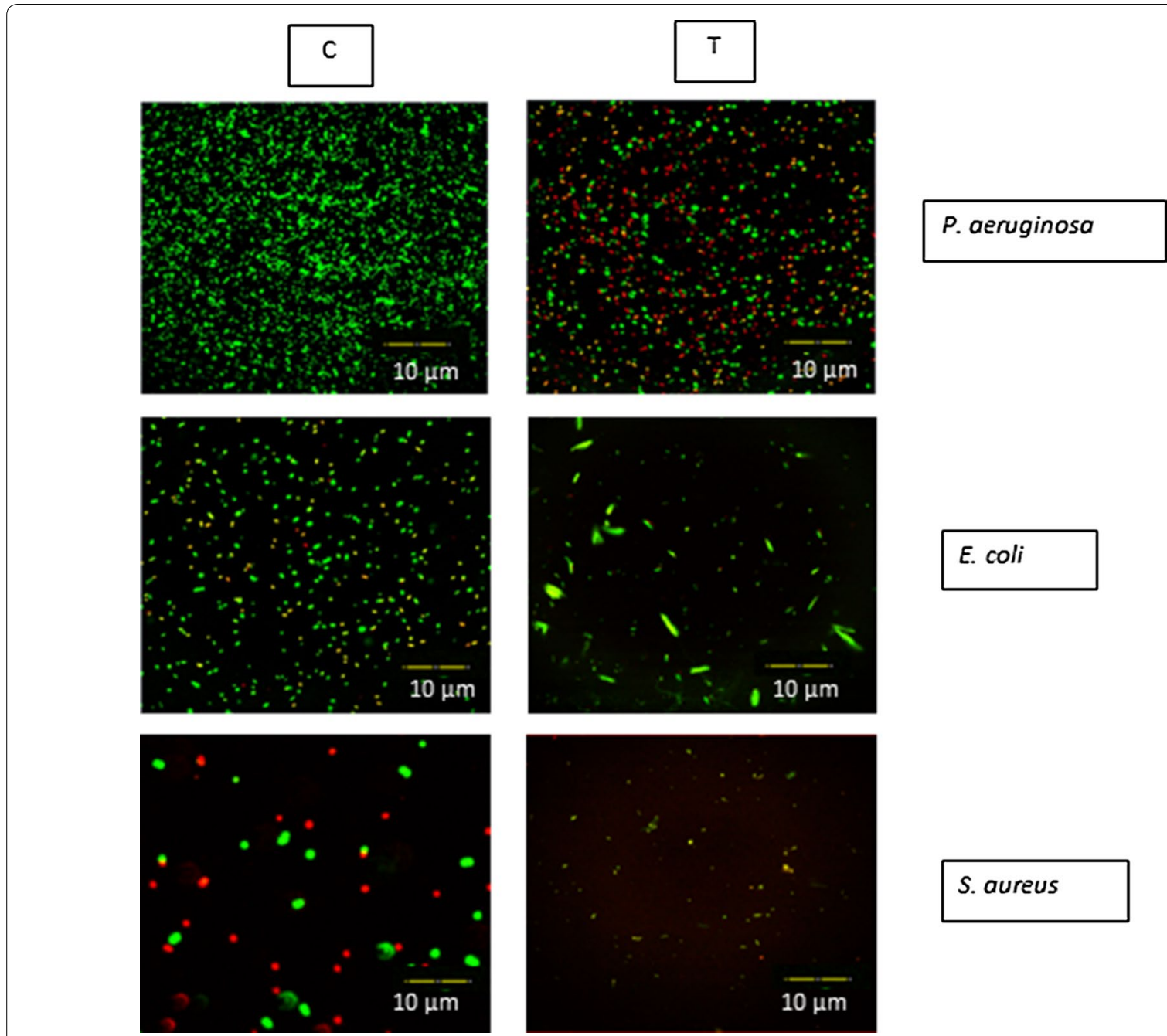

Fig. 3 Live cells of the different bacterial biofilm measured by CLSM after a treatment therapy with a selective digestive decontamination solution. C positive control; $T$ treated sample

samples $(p=0.002)$ (Table 1$)$. Total number of $\mathrm{cfu} / \mathrm{ml}$ are collected in supplementary material (Additonal file 1: Table S1). This represented that non-culturable cells were collected either from P. aeruginosa, E. coli, or S. aureus biofilms. Thickness and biofilm structure visualized by CLSM and SEM are shown in Fig. 4. Positive controls are characterized by a thickness layer of cells embedded into an extracellular matrix (ECM) whereas in treated samples, the ECM was disrupted, and abnormalities in cell size and shape were observed.

\section{Prophylactic therapy (ALP)}

In the ALP, there was absence of live cells of $P$ aeruginosa, E. coli, and $S$. aureus treated samples, $\mathrm{p}<0.001$, $\mathrm{p}<0.001$, and $\mathrm{p}=0.008$, respectively (Table 1 and Fig. 5). Besides, there was also absence of $\mathrm{cfu} / \mathrm{ml}$ counts for the 3 microorganisms (limit of detection $<10 \mathrm{cfu} / \mathrm{ml}$ )
( $\mathrm{p}=0.004$ for $P$. aeruginosa and $\mathrm{p}=0.002$ for $E$. coli and $S$. aureus). Total number of $\mathrm{cfu} / \mathrm{ml}$ are collected in Additional file (Additional file 1: Table S1). Figure 6 illustrates changes in thickness and biofilm structure after prophylactic therapy with SDDs compared with positive controls when visualized with CLSM and SEM. Using SEM we observed how ECM disappeared in treated samples, making bacteria vulnerable to antibiotics, and only antibiotic crystals and cell debris were presented on ETT surface after the therapy.

\section{Filtration testing}

In the bench-top model the Falcon tube represented the trachea of the patient. We did not recovered any volume of SDDs or saline in the tube after finishing the ALT and ALP therapies. Hence, all the treatments were retained in the cuff of the ETT. 


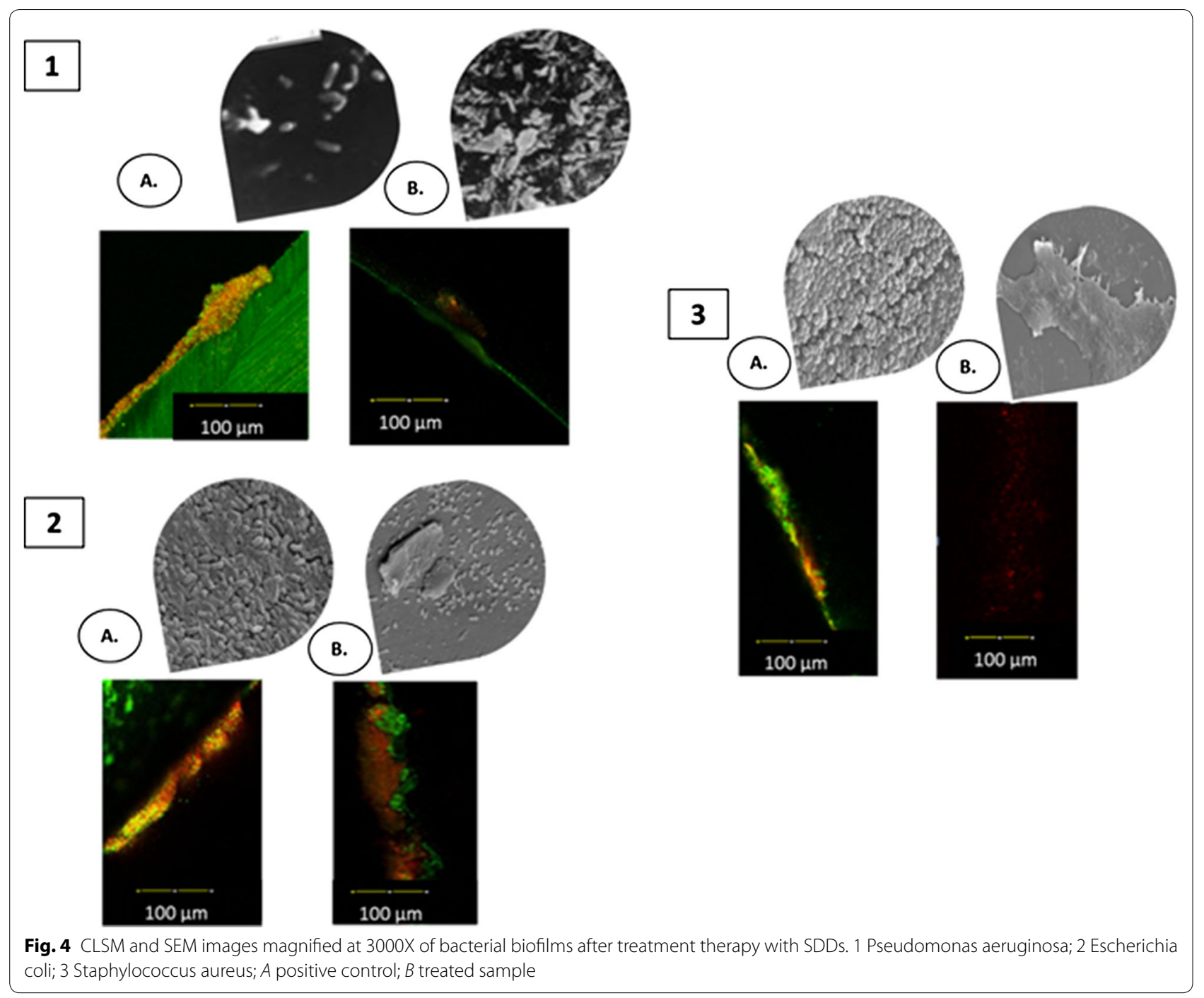

\section{Discussion}

Ventilator-associated pneumonia still represents a challenge in ICU patients with an incidence up to $24 \%$, an attributable mortality of $13 \%$ and an increase of hospital costs of around US\$55,882 per patient [33, 34]. A wide variety of preventing measures have been proposed by the Society for Health Epidemiology of America (SHEA) and IDSA including daily oral care, semi-recumbent position, subglottic secretion aspiration, and SDD [19, 34-36]. Most of these measures are based mainly on the decolonization of the internal surface of the ETTs. However, it has been demonstrated that bacterial biofilm can also be formed on the external surface of ETTs [37].

Under this basis, we conducted an in vitro study using a bench-top model of adult trachea intubation where we have demonstrated that SDD can be applied as lock therapy for the prevention of biofilm formation in the external surface of the subglottic space of ETT with an efficacy of $100 \%$ for P. aeruginosa ATCC 15442, E.coli ATCC 25922, and S. aureus ATCC 29213. Based on the possibility to prevent VAP, other authors have demonstrated other procedures to prevent biofilm formation. Machado et al., have recently described a novel way of preventing biofilm formation on ETT surface by nanomodifying polyvinyl with a fungal lipase $[38,39]$. They also demonstrated that these modifications reduced $P$. aeruginosa colonization by $2.7 \log _{10}$ [40]. However, no total reduction was observed. In our study, no live or cultivable cells appeared after the prophylactic therapy with SDDs. Another study conducted by Wang et al., an inhibition of $P$. aeruginosa biofilm formation was achieved using ultrasonic guided waves on a new model of ETT [41]. Although ultrasonic guided waves are a promising technology, it is still more cost effective than SDDs. Furthermore, we have previously demonstrated that promising results were obtained for $P$. aeruginosa biofilm reduction 


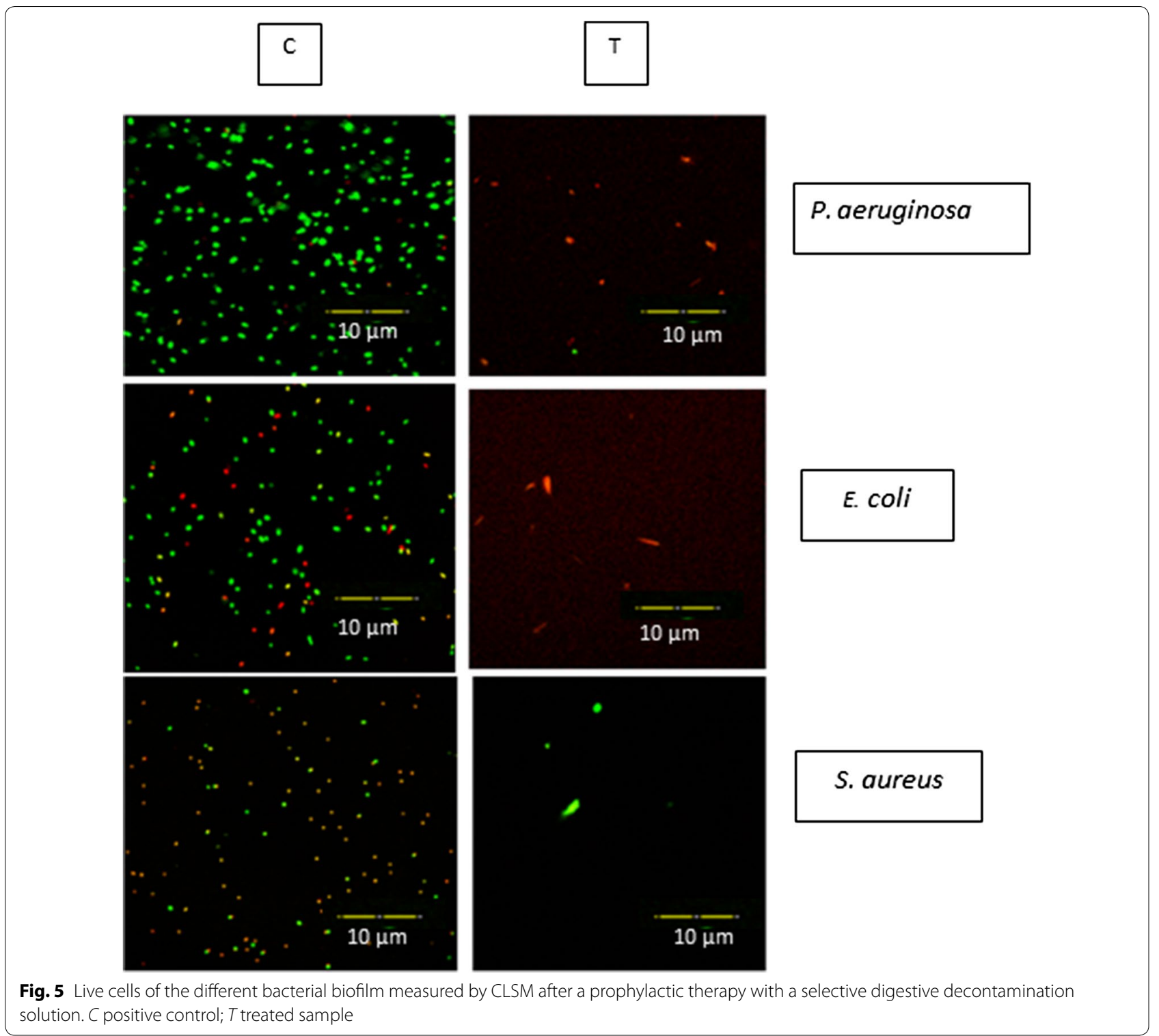

using SDDs as treatment therapy comparing single-dose and 5-day locking therapy in our model [42]. Thus, more studies are needed to test its efficacy against other microorganisms and to prove the application as a preventive measure.

$P$. aeruginosa, $S$. aureus, and $E$. coli are the three main representative microorganisms of VAP with an incidence of $13.1 \%, 28.3 \%$, and $6 \%$, respectively [43]. Literature about prevention of $P$. aeruginosa colonization in ETT is wide spread but ours is the first study in which prophylactic therapy has been performed in three different microorganisms with successful results for all of them.

Another key point in the management of VAP is the treatment. Although preventing measures have been described of being efficient, bacteria biofilm is still difficult to eradicate from ETT surface due to chronicity of infections and treatment failure [9]. We noted that SDDs reduced a pre-formed biofilm of $P$. aeruginosa, $E$. coli, and $S$. aureus. Although percentage of live cell reduction did not achieve $75 \%$ in $P$. aeruginosa and $E$. coli, it could be used as supportive treatment for actual therapies. In contrast, when measured by cfu counts, the percentage of reduction is $100 \%$. We hypothesize that this issue is explained by the viable but non-culturable (VBNC) cell phenomena. It is characterized by the ability of bacteria of reducing their metabolic activity and change their membranes and walls to survive under unfavorable conditions such as starvation or high stress [44]. During the 5 day ALT, bacteria are exposed to high doses of antibiotic leading to an adaptive response in a try of 


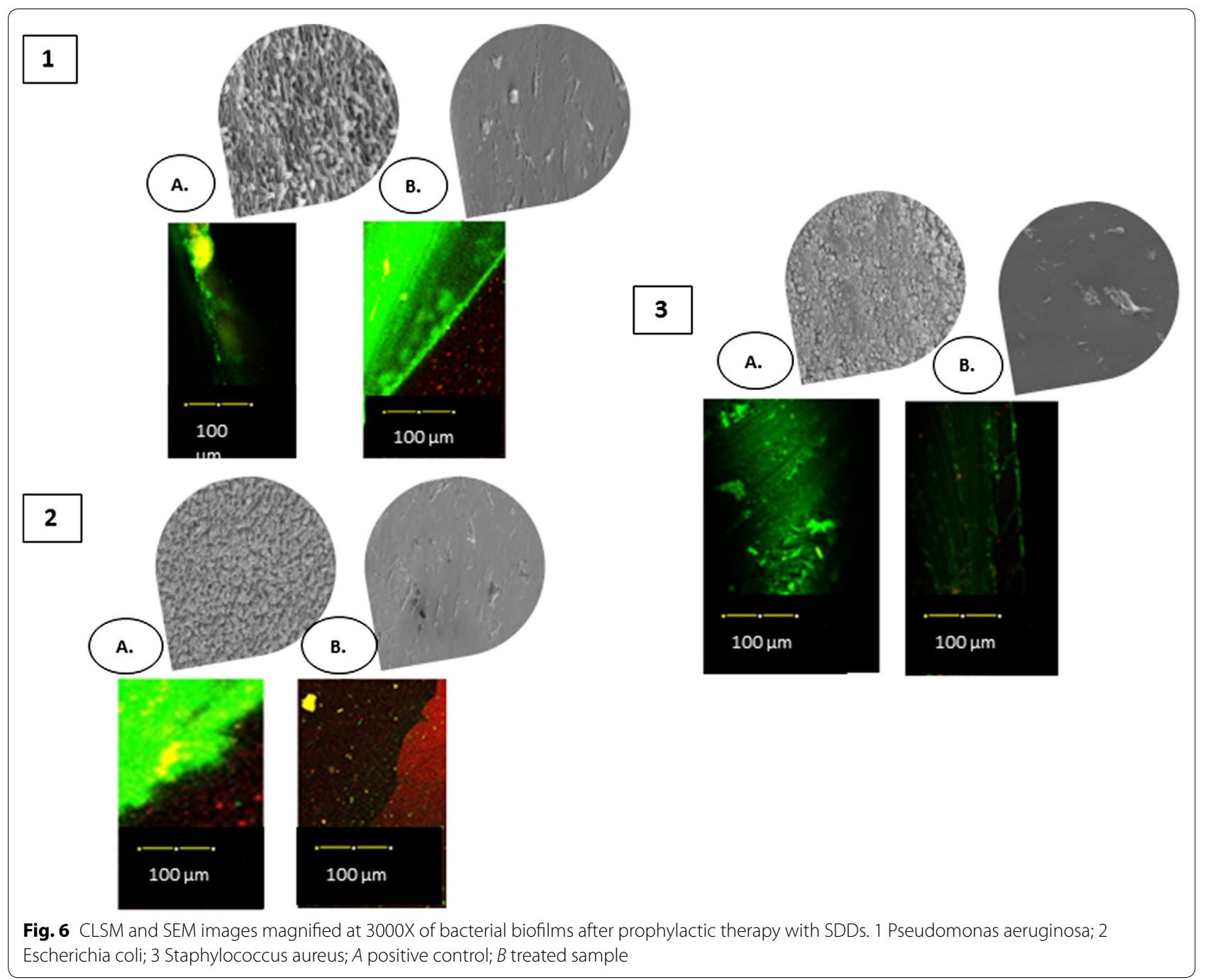

survival making diagnose and treatment by classical methods more challenging. As commented in the study of $\mathrm{Li}$ et al., the role of VBNC cells is still under discussion. Some authors support the hypothesis that these cells are in a preliminary phase of dying and is believed to have no clinical impact. Other authors consider that VBNC cells would have the ability to revive. However, in the prophylactic group of our study, neither cfu nor viable cells were recovered from any of the microorganisms tested. This means that VBNC cells were not present and therefore it would not have a negative impact in a clinical scenario.

In $S$. aureus, we have observed that SDDs supplemented with vancomycin eradicated bacteria biofilm in a $100 \%$. In a study presented by Fernandez-Barat et al., they evaluated the capacity of vancomycin versus linezolid to eradicate $S$. aureus methicillin-resistant biofilm on ETT surface o ventilated pigs [32]. They observed that i.v. linezolid was statistically significant better than vancomycin but no eradication was obtained. Thus, the administration of linezolid plus ALT with SDDs could achieve better results in vivo for VAP treatment. Although VBNC was not observed in S. aureus model, vancomycin and daptomycin have shown to induce significant rates of viable but non-culturable $S$. aureus cells $[45,46]$.

Regarding the clinical application of this procedure, Penumatikos et al. have previously demonstrated in a clinical study that VAP was significantly reduced when continuous infusion of antibiotic solution was applied at the subglottic space in trauma patients [29]. However, they administered the antibiotic solution by continuous infusion, which seems more difficult to manage in ICU patients. We consider a more easy-to-use regimen with a 30 min-lock therapy applied per nursing shift (every $6 \mathrm{~h}$ ) just immediately before subglottic aspiration. However, as we only demonstrated that there was no evidence of leaking past the cuff of the ETT in the in vitro model, it 
is necessary to validate this finding in a real clinical scenario to assess that this regimen would be a safety procedure to be performed in intubated critical patients. We consider that when a "lock therapy" at the subglottic space is aimed it may not cause damage to the patient because of SDDs filtration to the lungs mainly because of the continuous cuff pressure monitoring $>20 \mathrm{~cm} \mathrm{H}_{2} \mathrm{O}$, as recommended by the guidelines [18].

Although our in vitro bench-top model mimics the ETT subglottic conditions during patient-use of this device, it was a static model that may not simulate the real scenario in an intubated patient. Moreover, SDD could not reach the distal ETT and the cuff, however, as SDD is also applied by gastrointestinal and oral sources, it could reach other parts than the subglottic space. Methodologically, we have not used any neutralizer to inactivate the antibiotics before plating which may limit the VBNC bacteria growth although there is still no consensus about neutralizers and VBNC cells. Besides, guidelines do not contemplate its use in clinical samples except for decontamination before processing samples for mycobacteria cultures $[44,47,48]$. Another limitation of the study was the small amount of microorganisms used. We used the three main representative microorganisms to cause VAP in our institution. However, these results may not be extrapolated to others institutions where $P$. aeruginosa, E. coli and S. aureus represent low rates of VAP, and hence, further studies should be perform with other etiological pathogens. Our results must be validated in the real clinical practice by randomized clinical trials.

\section{Conclusion}

Ours is the first study to demonstrate that SDDs used as lock therapy in the subglottic space can represent an additional successful prophylactic measure against the biofilm of three of the most common microorganisms causing VAP. This means that it could be used in combination with traditional oral and digestive decolonization procedure, as it also demonstrated not to cause antibiotic resistance [26, 27, 49-51]. Further clinical investigations should be performed to evaluate its efficacy and safety in clinical settings.

\section{Supplementary information}

Supplementary information accompanies this paper at https://doi. org/10.1186/s12941-020-00387-7.

Additional file 1: Table S1. Cfu/ml counts for P. aeruginosa, E. coli and S. aureus after treatment and prophylactic therapies with SDD lock solution. Figure S1. Flowchart of the procedure for prophylaxis and treatment therapy of SDD lock solution in ETT.
Abbreviations

TSB: Tryptic soy broth; BHI: Brain heart infusion; LB: Luria broth; PBS: Phosphate buffer solution.

\section{Acknowledgements}

We thank Thomas O'Boyle for his help in the preparation of the manuscript. We thank Ana Vicente from the Centro Nacional de Microscopía Electrónica (ICTS-CNME, Universidad Complutense de Madrid, Spain) for her help in the preparation of the samples and the analysis of the SEM images.

\section{Authors' contributions}

MJPG, BA, and MG contributed in the conception and design of the study and had full access to all of the study data. MCL, RZ, RS, and BA made substantial contributions to acquisition, analysis, and interpretation of data. JH, MJPG, $\mathrm{PM}$ and EB contributed substantially to the study design, data analysis and interpretation, and the writing of the manuscript. MG contributed to the conception and design of the study and data analysis and interpretation and was involved in drafting the manuscript and critically reviewing it for important intellectual content. She takes responsibility for the integrity of the data and the accuracy of the data analysis. All authors read and approved the final manuscript.

\section{Funding}

M. Guembe is supported by the Miguel Servet Program (ISCIII-MICINN, CP13/00268) from the Health Research Fund (FIS) of the Carlos III Health Institute (ISCIII), Madrid, Spain. Beatriz Alonso is supported by the Consejería de Educación, Juventud y Deporte de la Comunidad de Madrid and Fondo Social Europeo (PEJ15/BIO/AI-0406). The study was partially financed by grants of the ISCIII (PI18/00045) and the European Regional Development Fund (FEDER) "A way of making Europe" and by grants from the Instituto de Investigación Sanitaria Gregorio Marañón (liSGM).

\section{Availability of data and materials}

Data sharing is not applicable to this article as no datasets were generated or analysed during the current study.

\section{Ethics approval and consent to participate}

Not applicable.

Consent for publication

Not applicable.

\section{Competing interests}

The authors declare that they have no competing interests.

\section{Author details}

${ }^{1}$ Cardiac Surgery Postoperative Care Unit, Hospital General Universitario Gregorio Marañón, Madrid 28007, Spain. ${ }^{2}$ Instituto de Investigación Sanitaria Gregorio Marañón, Madrid 28009, Spain. ${ }^{3}$ CIBER Enfermedades RespiratoriasCIBERES, CB06/06/0058), Madrid, Spain. ${ }^{4}$ Department of Clinical Microbiology and Infectious Diseases, Hospital General Universitario Gregorio Marañón, Madrid 28007, Spain. ${ }^{5}$ Biology Department, School of Biology, Universidad Complutense de Madrid, Madrid 28040, Spain. ${ }^{6}$ Confocal Laser Scanning Microscopy Unit, Hospital General Universitario Gregorio Marañón, Madrid 28007, Spain. ${ }^{7}$ Medicine Department, School of Medicine, Universidad Complutense de Madrid, Madrid 28040, Spain. ${ }^{8}$ Servicio de Microbiología Clínica y Enfermedades Infecciosas, Instituto de Investigación Sanitaria Gregorio Marañón, Hospital General Universitario "Gregorio Marañón", C/. Dr. Esquerdo, 46, Madrid 28007, Spain.

Received: 24 June 2020 Accepted: 10 September 2020

Published online: 23 September 2020

\section{References}

1. Kalanuria AA, Ziai W, Mirski M. Ventilator-associated pneumonia in the ICU. Critical care. 2014;18(2):208.

2. Metersky ML, Kalil AC. New guidelines for nosocomial pneumonia. Curr Opin Pulmonary Med. 2017;23(3):211-7. 
3. Joseph NM, Sistla S, Dutta TK, Badhe AS, Parija SC. Ventilator-associated pneumonia: role of colonizers and value of routine endotracheal aspirate cultures. Int J Infect Dis. 2010;14(8):e723-9.

4. Perez Granda MJ, Barrio JM, Hortal J, Munoz P, Rincon C, Bouza E. Routine aspiration of subglottic secretions after major heart surgery: impact on the incidence of ventilator-associated pneumonia. J Hospital Infect. 2013;85(4):312-5.

5. Viderman D, Brotfain E, Khamzina Y, Kapanova G, Zhumadilov A, Poddighe $D$. Bacterial resistance in the intensive care unit of developing countries: report from a tertiary hospital in Kazakhstan. J Glob Antimicrob Resist. 2019:17:35-8.

6. Bassi GL, Ferrer M, Marti JD, Comaru T, Torres A. Ventilator-associated pneumonia. Seminars Respiratory Critical Care Med. 2014;35(4):469-81.

7. Wilson A, Gray D, Karakiozis J, Thomas J. Advanced endotracheal tube biofilm stage, not duration of intubation, is related to pneumonia. J Trauma Acute Care Surg. 2012;72(4):916-23.

8. Li Bassi G, Fernandez-Barat L, Saucedo L, Giunta V, Marti JD, Tavares Ranzani $\mathrm{O}$, et al. Endotracheal tube biofilm translocation in the lateral Trendelenburg position. Critical Care. 2015;19:59.

9. Fernandez-Barat L, Torres A. Biofilms in ventilator-associated pneumonia. Future Microbiol. 2016.

10. Gil-Perotin S, Ramirez P, Marti V, Sahuquillo JM, Gonzalez E, Calleja I, et al. Implications of endotracheal tube biofilm in ventilator-associated pneumonia response: a state of concept. Critical Care. 2012;16(3):R93.

11. Oliveira J, Zagalo C, Cavaco-Silva P. Prevention of ventilator-associated pneumonia. Rev Port Pneumol. 2014;20(3):152-61.

12. Li Bassi G, Senussi T, Aguilera Xiol E. Prevention of ventilator-associated pneumonia. Curr Opin Infect Dis. 2017;30(2):214-20.

13. Berra L, Coppadoro A, Bittner EA, Kolobow T, Laquerriere P, Pohlmann $J R$, et al. A clinical assessment of the Mucus Shaver: a device to keep the endotracheal tube free from secretions. Crit Care Med. 2012:40(1):119-24.

14. Marra AR, Cal RG, Silva CV, Caserta RA, Paes AT, Moura DF Jr, et al. Successful prevention of ventilator-associated pneumonia in an intensive care setting. Am J Infect Control. 2009;37(8):619-25.

15. Berra L, De Marchi L, Yu ZX, Laquerriere P, Baccarelli A, Kolobow T. Endotracheal tubes coated with antiseptics decrease bacterial colonization of the ventilator circuits, lungs, and endotracheal tube. Anesthesiology. 2004;100(6):1446-56.

16. Kollef MH, Afessa B, Anzueto A, Veremakis C, Kerr KM, Margolis BD, et al. Silver-coated endotracheal tubes and incidence of ventilator-associated pneumonia: the NASCENT randomized trial. JAMA. 2008;300(7):805-13.

17. Ramirez P, Bassi GL, Torres A. Measures to prevent nosocomial infections during mechanical ventilation. Curr Opin Critic Care. 2012;18(1):86-92.

18. Guidelines for the management of adults with hospital-acquired. ventilator-associated, and healthcare-associated pneumonia. Am J Respir Crit Care Med. 2005:171(4):388-416.

19. Klompas M, Branson R, Eichenwald EC, Greene LR, Howell MD, Lee G, et al. Strategies to prevent ventilator-associated pneumonia in acute care hospitals: 2014 update. Infect Control Hosp Epidemiol. 2014;35(Suppl 2):S133-54

20. de Smet AM, Kluytmans JA, Cooper BS, Mascini EM, Benus RF, van der Werf TS, et al. Decontamination of the digestive tract and oropharynx in ICU patients. New England J Med. 2009;360(1):20-31.

21. Plantinga NL, de Smet AMG, Oostdijk EA, de Jonge E, Camus C, Krueger WA, et al. Selective Digestive and Oropharyngeal Decontamination in medical and surgical ICU-patients; an individual patient data metaanalysis. Clinical microbiology and infection: the official publication of the European Society of Clinical Microbiology and Infectious Diseases. 2017.

22. Schnabel RM, Scholte JB, Van Der Velden KE, Roekaerts PM, Bergmans DC. Ventilator-associated pneumonia rates after introducing selective digestive tract decontamination. Infect Dis. 2015;47(9):650-3.

23. Adair CG, Gorman SP, O'Neill FB, McClurg B, Goldsmith EC, Webb CH. Selective decontamination of the digestive tract (SDD) does not prevent the formation of microbial biofilms on endotracheal tubes. J Antimicrob Chemother. 1993;31(5):689-97.

24. Vandecandelaere I, Matthijs N, Van Nieuwerburgh F, Deforce D, Vosters $P$, De Bus $L$, et al. Assessment of microbial diversity in biofilms recovered from endotracheal tubes using culture dependent and independent approaches. PLoS ONE. 2012;7(6):e38401.

25. Singh G, Srinivasan R, Cheng J, Peng Z, Fujimura K, Baek MS, et al. Rearrangement of a large novel Pseudomonas aeruginosa gene island in strains isolated from a patient developing ventilator-associated pneumonia. J Clin Microbiol. 2014;52(7):2430-8.

26. de Jonge E, Schultz MJ, Spanjaard L, Bossuyt PM, Vroom MB, Dankert J, et al. Effects of selective decontamination of digestive tract on mortality and acquisition of resistant bacteria in intensive care: a randomised controlled trial. Lancet. 2003;362(9389):1011-6.

27. Ochoa-Ardila ME, Garcia-Canas A, Gomez-Mediavilla K, Gonzalez-Torralba A, Alia I, Garcia-Hierro P, et al. Long-term use of selective decontamination of the digestive tract does not increase antibiotic resistance: a 5-year prospective cohort study. Intens Care Med. 2011;37(9):1458-65.

28. Price R, MacLennan G, Glen J. Selective digestive or oropharyngeal decontamination and topical oropharyngeal chlorhexidine for prevention of death in general intensive care: systematic review and network meta-analysis. BMJ. 2014;348:g2197.

29. Pneumatikos IA, Dragoumanis CK, Bouros DE. Ventilator-associated pneumonia or endotracheal tube-associated pneumonia? An approach to the pathogenesis and preventive strategies emphasizing the importance of endotracheal tube. Anesthesiology. 2009;1 10(3):673-80.

30. Yoshimura J, Kinoshita T, Yamakawa K, Matsushima A, Nakamoto N, Hamasaki T, et al. Impact of Gram stain results on initial treatment selection in patients with ventilator-associated pneumonia: a retrospective analysis of two treatment algorithms. Critical Care. 2017;21(1):156.

31. Carter EL, Duguid A, Ercole A, Matta B, Burnstein RM, Veenith T. Strategies to prevent ventilation-associated pneumonia: the effect of cuff pressure monitoring techniques and tracheal tube type on aspiration of subglottic secretions: an in vitro study. Eur J Anaesthesiol. 2014;31(3):166-71.

32. Fernández-Barat L, Li Bassi G, Ferrer M, Bosch A, Calvo M, Vila J, et al. Direct analysis of bacterial viability in endotracheal tube biofilm from a pig model of methicillin-resistant Staphylococcus aureus pneumonia following antimicrobial therapy. FEMS Immunol Med Microbiol. 2012;65(2):309-17.

33. Zaragoza R, Vidal-Cortés P, Aguilar G, Borges M, Diaz E, Ferrer R, et al. Update of the treatment of nosocomial pneumonia in the ICU. Crit Care. 2020;24(1):383.

34. Colombo SM, Palomeque AC, Li Bassi G. The zero-VAP sophistry and controversies surrounding prevention of ventilator-associated pneumonia. Intensive Care Med. 462020. p. 368-71.

35. Kalil AC, Metersky ML, Klompas M, Muscedere J, Sweeney DA, Palmer $L B$, et al. Management of adults with hospital-acquired and ventilatorassociated pneumonia: 2016 clinical practice guidelines by the infectious diseases society of America and the American thoracic society. Clin Infect Dis. 2016:63(5):e61-111.

36. Ekren PK, Ranzani OT, Ceccato A, Li Bassi G, Munoz Conejero E, Ferrer M, et al. Evaluation of the 2016 Infectious Diseases Society of America/ American Thoracic Society Guideline Criteria for Risk of Multi-drug Resistant Pathogens in Hospital-acquired and Ventilator-associated Pneumonia Patients in the Intensive Care Unit. American journal of respiratory and critical care medicine. 2017.

37. De Souza PR, De Andrade D, Cabral DB, Watanabe E. Endotracheal tube biofilm and ventilator-associated pneumonia with mechanical ventilation. Microsc Res Tech. 2014;77(4):305-12.

38. Machado MC, Webster TJ. Lipase degradation of plasticized polyvinyl chloride endotracheal tube surfaces to create nanoscale features. Int J Nanomed. 2017;12:2109-15.

39. Hashemi MM, Rovig J, Bateman J, Holden BS, Modelzelewski T, Gueorguieva I, et al. Preclinical testing of a broad-spectrum antimicrobial endotracheal tube coated with an innate immune synthetic mimic. J Antimicrob Chemother. 2018;73(1):143-50.

40. Machado MC, Webster TJ. Decreased Pseudomonas aeruginosa biofilm formation on nanomodified endotracheal tubes: a dynamic lung model. Int J Nanomed. 2016;11:3825-31.

41. Wang H, Teng F, Yang X, Guo X, Tu J, Zhang C, et al. Preventing microbial biofilms on catheter tubes using ultrasonic guided waves. Sci Rep. 2017;7(1):616.

42. Perez-Granda MJ, Latorre MC, Alonso B, Hortal J, Samaniego R, Bouza E, et al. Eradication of $\mathrm{P}$ aeruginosa biofilm in endotracheal tubes based on lock therapy: results from an in vitro study. BMC Infect Dis. 2017;17(1):746.

43. Roberts KL, Kollef MH, Micek ST, Juang P. Controversies and advances in the management of ventilator associated pneumonia. Expert Rev Respir Med. 2017. 
44. Li L, Mendis N, Trigui H, Oliver JD, Faucher SP. The importance of the viable but non-culturable state in human bacterial pathogens. Front Microbiol. 2014;5:258.

45. Goncalves FD, de Carvalho CC. Phenotypic modifications in Staphylococcus aureus cells exposed to high concentrations of vancomycin and teicoplanin. Front Microbiol. 2016;7:13

46. Pasquaroli S, Citterio B, Cesare AD, Amiri M, Manti A, Vuotto C, et al. Role of daptomycin in the induction and persistence of the viable but non-culturable state of Staphylococcus aureus biofilms. Pathogens. 2014;3(3):759-68.

47. Hoiby N, Bjarnsholt T, Moser C, Bassi GL, Coenye T, Donelli G, et al. ESCMID guideline for the diagnosis and treatment of biofilm infections 2014. Clin Microbiol Infect. 2015;21(Suppl 1):S1-25.

48. Muzanye G, Morgan K, Johnson J, Mayanja-Kizza H. Impact of mouth rinsing before sputum collection on culture contamination. Afr Health Sci. 2009;9(3):200
49. de Jonge E. Effects of selective decontamination of digestive tract on mortality and antibiotic resistance in the intensive-care unit. Curr Opin Crit Care. 2005;11(2):144-9.

50. Daneman N, Sarwar S, Fowler RA, Cuthbertson BH. Effect of selective decontamination on antimicrobial resistance in intensive care units: a systematic review and meta-analysis. Lancet Infect Dis. 2013;13(4):328-41.

51. Leone M, Albanese J, Antonini F, Nguyen-Michel A, Martin C. Long-term (6-year) effect of selective digestive decontamination on antimicrobial resistance in intensive care, multiple-trauma patients. Crit Care Med. 2003;31(8):2090-5.

\section{Publisher's Note}

Springer Nature remains neutral with regard to jurisdictional claims in published maps and institutional affiliations.
Ready to submit your research? Choose BMC and benefit from:

- fast, convenient online submission

- thorough peer review by experienced researchers in your field

- rapid publication on acceptance

- support for research data, including large and complex data types

- gold Open Access which fosters wider collaboration and increased citations

- maximum visibility for your research: over $100 \mathrm{M}$ website views per year

At BMC, research is always in progress.

Learn more biomedcentral.com/submissions 